\title{
THE VEGETATION OF JAPAN.
}

BY

H. TAKEDA, ESQ., D.I.C.,

Royal College of Science, South Kensington, S.W.

[NEW PHYTOLOGIST REPRINT No. 6.]

PRICE - ONE SHILLING, POST FREe.

CAMBRIDGE :

AT THE BOTANY SCHOOL,

1913. 
Feb. 15, 1945

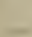




\section{THE VEGETATION OF JAPAN.}

BY

H. TAKEDA, ESQ, D.I.C.,

Royal College of Science, South Kensington, S.W.

[NEW PHYTOLOGIST REPRINT No. 6.]

CAMBRIDGE :

AT THE BOTANY SCHOOL,

1913. 



\section{THE VEGETATION OF JAPAN.}

By H. Takeda, D.I.C.

(Demonstrator in Botany, Royal College of Science, London).

[Reprinted from The New Phytologist, Vol. XII, No.2,

February, 1913].

\section{I.-INTRODUCTION.}

$\mathrm{M}$

ANY valuable and interesting papers dealing with certain constituents of the flora of Japan have been published by not a few botanists, both Japanese and foreign. Yet there has been lacking, so far as I am aware, a general account of the flora or vegetation of Japan, except perhaps in the form of a catalogue or enumeration of plants growing in that Empire. It has been suggested therefore that a brief description of the vegetation of Japan would be interesting to the readers of this journal. The present paper has been re-written from lectures addressed in 1912 to the Natural History Society of the Imperial College Union and to the Botanical Society of London, and it is proposed therein to give a general idea of the vegetation of Japan.

II.-Geographical Features and Climate of Japan.

The position occupied by Japan is somewhat similar to that of Britain, with this difference, that while the British Isles lie on the west of the European continent, the Islands of Japan are to the east of the mainland of Asia. Taking them in the order from north to south, the group of islands comprised in the present Empire of Japan consists of the Kurile Islands, the southern half of Saghalien, Yezo, the main island known to the Japanese as Hontô and occasionally called by Europeans Nippon, Shikoku, Kyûshû, the Loochoos, Formosa, and the Pescadores. These islands stretch diagonally from the 52 nd down to the 21 st degree of north latitude, and are situated between the 120th and 156th degrees of longitude east of Greenwich. The above described area of the Empire was 
increased in August, 1910 by the annexation of Corea, so that it has now much the same area ${ }^{1}$ as that of Austria-Hungary, and the population $^{3}$ is nearly equal to that of Germany. A warm current called "Kuroshio", similar to the Gulf stream of northern Europe, originating between Luzon and Formosa, flowing past the eastern side of the latter and along the southern Loochoos, reaches the southern extremity of Kyûshû, where it divides into two branches. Whilst the main stream bends northward and flows along the south. east coast of Kyûshû, Shilioku, and Hontô, the smaller branch washes the west of Kyûshû and the Gotô group and runs up to the Sea of Japan through Tsushima or Krusenstern Strait. This so-called Tsushima Stream flows over the eastern half of the Sea of Japan from the south-west to the north-east and passes partly through Tsugaru Strait, but mainly through Lapérouse Strait, and soon dimishes when it reaches the southern part of the Sea of Okhotsk. The main division of the "Kuroshio" bends out into the Pacific Ocean about the 39th degree of latitude and talses a course towards the south of the Aleutian Islands and the coast of North America.

The cold currents in the northern Pacific Ocean, which affect the climate of Japan, originate partly in the Sea of Okhotsk and partly in the Behring Sea. The Kurile Stream, the most important of these, starts in the Penshina and Gishiga Bays and flows southwards along Kamtschatka, and then taking up a wealser current from the eastern side of this large Siberian peninsula, turns towards the Kuriles and washes the whole length of the chain of islands. The current then runs chiefly along the east-coast of Yezo, down to the 39 th degree of latitude, ${ }^{2}$ where the above-mentioned main stream of the warm current bends away into the Pacific Ocean. The water of this current is very cold and even in the summer its temperature does not rise above $5^{\circ} \mathrm{C}$.

These warm and cold currents exercise great influence over the distribution of seaweeds. This is clearly seen on the east coast of Japan, the 39th degree of latitude being the separating point of two different algal floras. On the west coast, however, the course of the currents is more complicated, so that the elements of different floras appear somewhat intermixed, as will be seen from the following examples.

The strand-flora is similarly affected, the northern elements

1256,033 square miles. ${ }^{2} 63,037,518$. (Estimated in August, 1912).

2 Occasionally it comes down as far south as the 38 th degree. 


\section{The Vegetation of Japan.}

being distributed in the localities touched by the cold currents. To give some examples: Mertensia maritima is to be seen in the Okhotsk region, on the coast of Manchuria down to North Corea, while in the main island of Japan and especially on its east coast it is found northward from the 38th degree of latitude. Strictly speaking this plant, as it grows in the Far East differs, from the typical form of Europe and America, in having a stouter stem, and larger and more showy flowers, and it is recognised as a suh. species under the name of asiatica. ${ }^{1}$ This sub-species is also found in various places on the Behring Sea. Glaux maritima, another arctic plant, which we meet with in various places in the British Isles, is distributed in Japan mainly from Yezo northward. But we also find this pretty seashore plant at a spot on the western coast of Hontô, whither the plant has probably been carried by the cold currents. Plantago camtschatica is another plant which is to be found in the localities visited by the cold currents.

The warm current has a similar influence on the distribution of plants ; it is the important current by which our ancestors reached Japan in remote antiquity. ${ }^{2}$ As this current comes into direct contact with the southern parts of Kyûshû, Shilkoku, and Kii, various sub-tropical plants are found in these places. To give a few examples: Rhizophora mucronata is found at Kagoshima (32 N.L.); Senecio scandens in Tosa (Shikoku) and Kii; Pteris Wallichiana in Kii; Asplenium Nidus in Kii and the Gotô group; Ipomaea biloba (=I. pescapra), in Echigo. Statice japonica which is mainly distributed in south-western Japan, is also to be found on the east coast as far north as the 38 th degree of latitude.

Leaving the coast, let us now proceed inland and see what the country is like. The islands comprising Japan are all mountainous; there is no place from which we cannot see a prominent hill. Not a few of the smaller islands simply consist of one or more volcanoes. The great majority of the high mountains are densely clad with luxuriant vegetation from the foot right up to the summit-often so densely indeed, as to render the thick mountain-forests almost impenetrable. The mountains are generally lofty and exhibit the finest scenery of the country. The grandest mountain-chains are to be seen in Central Japan where they form the back-bone of Hontô, rising in places to an elevation of 10,000 feet. The higher pealss are made up partly of palæozoic, partly of plutonic, and partly

Cf. Journ. Bot., 1911, p. 222.

2 Said to have been some 3,000 years ago. 
of volcanic rocks. The youngest of the volcanic rocks, the ande site, broke not only through the various sedimentary rocks, but also through the granite, porphyry, and liparite. Although their altitude is so considerable, the mountains of Japan contain no glaciers, but slight traces belonging to an earlier period were discovered in 1902 . There is, however, a great deal of névé present on some of the mountains, Mountaineering amongst the high peaks is very instructive, but the ascent is sometimes impeded by thick forest, so that it is necessary to follow a torrent, crossing it again and again until a waterfall intervenes, and then the bank has to be climbed. Sometimes the ascent is made by climbing a field of perpetual snow filling up a gully. Little mountaineering was done, except on certain peaks, until 1905, when the Alpine Club of Japan was organised. Since then very many men have spent their holidays amongst the mountains, climbing peaks where no educated person had been before, or following along huge mountain-chains, to find some new route, or discover new plants.

As the mountainous character of the country would suggest, Japan is naturally very rich in water. A dense network of rivers, torrents and lakes is to be seen nearly everywhere. With a few exceptions, the rivers are short and their gradient steep, causing frequent floods. In the late spring, when the snow which has gathered in the mountains during the winter, begins to melt, or when in the summer the continuous rain carried by the S.W. monsoon frequently falls in torrents, the water flows down in every mountain-furrow, and converts the small cheerful mountain-rivulet into an enormous stream. With the clashing of the muddy water, mixes the thundering sound of pieces of rock rolling over the bottom, carried down by the waves together with the lightly-built bridges and planks. Further down even the solid banks, carefully constructed on both sides of the wide stream, are not always able to withstand the power of the great mass of water or to check its work of devastation.

The numerous waters add a special charm to the magnificent woodland scenery of the mountains. The small stream, rich in trout, carries its clear waters in many directions, sometimes passing huge rocks adorned with pretty shrubs and ferns, sometimes spreading over a boulder, then narrowing into a rocky gorge shaded by bushes and foliage, here hurriedly setting over rocks and covered with white foam, there slowly winding round a projecting rock which appears to arrest its course. Where the water has hollowed 
out the bed, the purest blue green of the clear water may be enjoyed. It is generally considered in Japan, that a landscape is perfect only when water is present.

Very good examples of beautifully developed picturesque valleys can be seen amongst the greater archæan and palæozoic mountains. Here the various degrees of hardness and folding of the rocks offer a very unequal resistance to the weathering and eroding power of the running water.

It only remains now to mention the climate. As I have already pointed out, the Empire of Japan stretches over 30 degrees of latitude. Owing to this considerable length and the great variety in the orographic character of the country, uniformity of climate is out of the question, but to deal with this in detail would occupy too much space. In a word, the climate is much influenced by that of the neighbouring countries, and is modified by the warm and cold currents previously mentioned. The climate of the region from Formosa northward up to the mouth of the Amur River is practically under the control of the monsoons, which are formed by the warm damp south wind in the summer and cold strong north-west, north, and north-east winds in the winter. The Loochoos down to Formosa are sub-tropical and have practically no winter, while the Kuriles, the southern portion of Saghalien, which now again belongs to Japan, and certain parts of Yezo have the climate of Nova Scotia or Iceland. In the winter drifting ice is carried along by the currents and wind in the Kuriles and blocks up harbours, so that navigation is impracticable from November to April. On the northernmost islands of this chain, not until June does the snow disappear from the ground and vegetation then comes to life. Even in the north-east of Hontô, and especially in the so-called deep-snow districts, the snow lies on the ground during the winter some twenty feet deep, so that a whole village is often buried.

The rainfall is very large, and especially in the summer, ${ }^{1}$ the air is very damp indeed, except in Hokkaidô (=Yezo and the Kuriles) which is not affected by the monsoon. The winter is dry and fine. The air is clear, the wind refreshing, and the sun bright. The seasons are very distinctly marked and the temperature is fairly even during each season. The annual range of heat and

1 An example of the rainfall in Tôky'o will be seen in the following table (in $\mathrm{mm}$.) :-

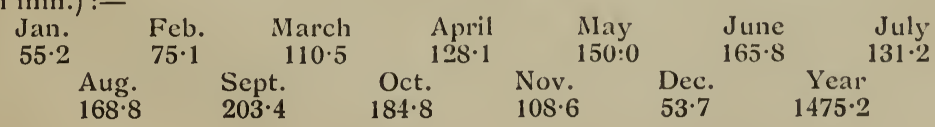


cold is, however, much greater than in Britain; e.g., in Tôkyô the mean temperature of the year is $13 \cdot 8^{\circ} \mathrm{C}$, the maximum being $36 \cdot 6$ and the minimum $9 \cdot 2^{0}{ }^{1}$

\section{III.-Comparison and Origin of the Flora.}

Under such geographical, geological, and climatic conditions one expects to find a well-developed, varied, and abundant flora. This expectation will be realised, for the traveller meets with beautiful vegetation and an endless variety of plants throughout the country. Up to 1904 some 4,400 species of Cryptogams were recorded, and in the Index of Japanese Plants which has just been completed some 6,000 species of Phanerogams are enumerated, ${ }^{2}$ we know, therefore, that there are not less than 10,000 species of plants indigenous to Japan. This number, however, does not include the plants of Saghalien and Corea, which came into the possession of Japan after the above-mentioned index was commenced. ${ }^{3}$ An exhaustive survey of plant-species is not yet possible, for new species and varieties are constantly being published.

The flora of Japan belongs to Drude's Eastern Asiatic Region. Although the Empire is surrounded by seas, in the west it is closely connected with Manchuria through Corea, in the north it reaches Kamtschatca by the Kurile Islands, and Alasla through the Aleutian Islands, and also has a connexion with Amurland through Saghalien. On the other hand the Loochoos and Formosa join it to Southern China, the Philippines and the East Indian Islands. Thus, except on the eastern side, it is closely connected with other countries, and their respective floras show many signs of a close relationship with that of Japan.

It is rather difficult to say exactly when the archipelago of Japan separated from the Asiatic Continent, but there is evidence that Japan was connected with the mainland of Asia until a comparatively recent period. Plants indigenous in the eastern parts of Asia are also found in Japan. Teeth and various bones of the mammoth have also been discovered in several parts of the country.

1 An example of the mean temperature in Tôkyô is as follows (in C.) :-

$\begin{array}{ccccccc}\text { Jan. } & \text { Feb. } & \text { March } & \text { April } & \text { May } & \text { June } & \text { July } \\ 2 \cdot 8 & 3 \cdot 6 & 6 \cdot 8 & 12 \cdot 4 & 16 \cdot 6 & 20 \cdot 4 & 24 \cdot 2 \\ \text { Aug. } & \text { Sept. } & \text { Oct. } & \text { Nov. } & \text { Dec. } & \text { Year } \\ 25 \cdot 6 & 22 \cdot 2 & 15 \cdot 8 & 10 \cdot 1 & 5 \cdot 1 & 13 \cdot 8\end{array}$

2 Matsumura, Index PI. Japonicarum, 1904-1912. The last volume of this Index includes but a few plants published after 1910 .

3 There are known more than 300 species of higher plants from the Japanese part of Saghalien, while in Corea there are roughly 2,150 species, of which about 200 are endemic. (The latter information was kindly supplied by Dr. T. Nakai, the author of Flova Koveana). 
The characteristics of the flora of Japan in general are first the abundance of species and varieties, secondly, the presence of a large number of endemic species, thirdly, the proportion of woody plants is remarkably high, and lastly, the presence of tropical and sub-tropical elements throughout the country. Even in Yezo, the large island of North Japan, are found many representatives of southern floras, such as Picrasma, Vitex, Rhus, Hydrangea, Lespedeza, Phellodendron, Avalia, Magnolia, and others growing together with representatives of the cold flora. In the northern parts of Hontô, Esculus, Zanthoxylon, Ardisia, Elaagnus, Smilax, and Camellia are often seen. The same or closely allied species have been found in the tertiary strata of the north of Eastern Asia. Probably in the middle of the tertiary period, even Saghalien had a much warmer climate, for at that time Ginkgo, Biota, Sequoia, and Nilssonia grew there. When, towards the end of the tertiary period, the greater part of the northern hemisphere was covered with ice, the main island of Japan seems to have suffered very little. Perhaps since the end of the glacial period and the change of climate in the middle diluvial age, Japan has maintained a fairly warm temperature, enabling many plants of warmer climates to survive, while in Saghalien the temperature has been very low, so that this island is unfavourable to plants of the warm temperate region. The arctic plants once compelled by the cold climate of the glacial period to come down southward were consequently left behind when the climate became warmer, but only persist on the summits of the high mountains.

Starting with the flora established in the tertiary period, the migration of arctic plants towards the south and of tropical plants towards the north has caused the present flora to be very complex. The connexion of the country with the northern, north-eastern south-eastern, and southern parts of the Asiatic continent made paths for arctic and tropical plants into Japan. The interruptions between the various islands are bridged over to some extent by the currents and wind. The introduction of seeds might not have been successful, if the conditions of climate and soil had not been so favourable. Evergreen trees and shrubs and many other tropical plants found their way by degrees towards the north, and became acclimatized-so we may presume - to the colder winter night and contented with comparatively high temperature during the day, and above all the warm and moist atmosphere during the summer, when they can obtain their vital requisites. Those which came 
from the north or north-west, where they were accustomed to a severe winter, migrated up the mountains until they obtained the necessary climatic conditions.

Migrations must also have taken place in the post-tertiary period, for the great majority of the volcanoes were built up then, and also the irregularity of the surface of the country was to some extent brought about at this time.

From the results of investigations of the tertiary fossils of Japan, of Amurland, and of N. America, the conclusion may be drawn that the present flora originated in the large common flora of the northern region of the Far East. Its development to its present condition has already been elucidated. One striking feature is that the flora of the N.E. part of Japan bears a close relationship to that of the Atlantic coast of $\mathrm{N}$. America. This was first noticed by Asa Gray a good many years ago. He endeavoured to compare the two floras and showed that more that $60 \%$ of Japanese plants grew on the E. coast of N. America, or if not, were represented by closely related species, while only $37 \%$ of these can be seen on the W. coast. He accordingly suggested that the close affinity between these floras originated in the tertiary period. Asa Gray's conclusion has been more and more firmly established as further geological evidence has accumulated, and consequently Engler and other geographical botanists have come to the conclusion that these two regions were actually connected, and had a similar climate and similar flora. After the glacial period many plants which migrated towards the south returned northwards and formed the foundation of the present flora of Japan, while in N. America, a change in climate had taken place between that of east and west While in the west the climate became dry and mild and caused a great alteration in the flora, in the east very little change has taken place, and many old species have been preserved.

It should be borne in mind, however, that the vegetation of Japan, except that of the northern islands, has little actual resemblance to that of $\mathrm{N}$. America. Although the same or closely allied plants occur in both regions, they are not found in the same proportion. For instance, in Japan Tsuga forms continuous and almost unbroken forests of great extent on the mountain slopes, above 5,000 feet from sea level, while in eastern N. America this tree is rarely found except scattered in small groves or as single individuals in the deciduous forests. On the other hand, Picea and Abies, which in America form immense forests almost to the 
exclusion of other species, in Central Japan grow singly or in small groves on the lower border of $T$ 'suga forests or mingled with broadleaved trees. In northern Japan and on the high mountains of Hontô, birches are more abundant than they are in the northern forests of America, and the river banks in the north, like those of N. Europe and Siberia, are lined with arborescent willows and alders, which are rare in eastern America, where these genera are usually represented by shrubs. This difference is due to the other dominant plants peculiar to each flora. The nnmber given in Gray's estimation should also be reduced slightly, since he included as natives some Chinese and Corean plants cultivated in Japan. Besides these and some endemic species, we have, as I have already remarked, a great many plants of the boreal region of the old world. For instance, Asperula odorata which occurs in Europe but not in America, grows abundantly in North Japan. In South Japan many tropical and sub-tropical elements may be seen. Certain plants growing in the central and southern parts of the country have also a close affinity to those of S. China as well as to those of the Himalayas.

\section{IV.-Regions of Vegetation.}

As has already been said, owing to the considerable length of the Empire, we cannot deal with the vegetation collectively, but are bound to divide it into certain regions. It may conveniently be arranged in three divisions mainly based on the climatic conditions:(1) Northern, (2) Middle, and (3) Southern Regions. The Northern Region extends from the 38th degree of latitude northwards to the Kuriles and Saghalien. We may also include in it the northern part of Corea. The Middle Region is formed of the greater part of Hontô and Shikoku, a small part in the north of Kyûshû, and South Corea. The Southern Region includes the southern parts of the province of $\mathrm{Kii}$ and Shikoku, the greater part of Kyûshû, the Bonin Islands, the Loochoos, Formosa, and the Pescadores.

We must note here that within each of these regions there exists a certain degree of difference in the vegetation, according as we consider the northern or the southern portion. The northern part of the Northern Region is represented by the arctic, and the southern part by the sub-arctic, with a few elements of the cold temperate flora. In the northern part of the Middle Region the plants of the cold temperate flora are to be found, and in its southern part those of the warm temperate. The Southern Region 
possesses warm temperate and sub-tropical plants in its northern part, and tropical plants in the southern.

\section{V.-Plant-Formations.}

In this chapter I intend to deal very briefly with various plantformations. For the sake of convenience, the above-mentioned three regions are treated separately.

1. Northern Region. The sea-coasts of this region are lined partly with sand-dunes and partly with cliffs. In Holkaidô, and especially in the Kuriles, sand-dunes are poorly developed. On the sand one generally finds Amodenia (Arenaria) peploides var. oblongifolia, Arabis japonica, A. perfoliata, Matricaria ambigua, Atriplex patula, Carex macrocephala, C. pumila, Elymus mollis, Geranium yezoense, Inula Psendo-Arnica, Lactuca repens, Linaria japonica, Lathyrus maritimns, Lilium dahuricum, Mertensia maritima subsp. asiatica, Phellopterus litoralis, Plantago camtschatica, Poa glumaris, Salsola soda, Thermopsis fabacea, etc. In the sea we often come across Phyllospadix Sconleri and Zostera pacifica. Just inside the sand-dunes Rosa rugosa, which is very often cultivated in English gardens, forms thiclets. Exposed parts of the cliff are often strikingly adorned with quantities of interesting arctic flowers, and even a small patch of rocks may form a beautiful garden. Some of the plants which we see here are as follows:-Androsace Chamajasme, Artemisia sacrornm, A. Schmidtianum, Chrysanthemum arcticum, Cochlearia oblongifolia, Conioselinmm cantschaticum, Draba borealis, Empetrum nigrum, Erigeron subsuginosus, Fritillaria camtschatcensis, Hedysarum obscurum var. neglectum, Leontopodium kurilense, Lignlaria sibirica, Lloydia alpina, Mertensia rivularis var. japonica, Oxytropis retusa, Parnassia palustris, Pedicnlaris venusta var. Schmidtii, Potentilla megalantha, Primula modesta var. Fauria, Rhododendron kamtschaticum, Salix arctica, Saxifraga bronchialis, S. cortusifolia, S. reflexa, Sedum camtschaticum, S. Rhodiola, Vaccinium Vitis-Idaea, and so forth.

The salt-marsh, which is not a rare formation in N. Europe, is very feebly developect. There are only three or four localities known where Salicornia is found. But in rather muddy places near the sea, one often comes across the pretty Glaux maritima and Triglochin maritimnm.

The dry hillsides are usually covered with Miscanthus, with which various species of Artemisia, Aconitum, Convallaria majalis, Geranium, Hemerocallis Middendorffi, Lespedeza, Platycodon, Rumex, and 
Umbelliferæ. In humid places of the mountain valleys we often find Artemisia vulgaris, Cacalia hastata, Lilium cordifolium, L. Glehni, Petasites japonicus, Polygonum sachalinense, Urtica platyphylla, and so on, most of which are very robust.

The Sphagnum bog or "Hochmoor," which is not much in evidence in the other regions, is here fairly well developed. The following plants are frequently met with:-Caltha palustris, Carex spp., Clematis fusca, Cormus suecica, Drosera rotundifolia, Eleocharis spp., Eriophorum alpinum, E. vaginatum, Gentiana jesoana, Ledum palustre var. dilatatum, Lonicera cornlea, Lycopodium clavatum, L. inundatum, Lysichiton camtschatcense, Molinia corulea, Myrica Gale var. tomentosa, Oxycoccus palustris, Phalaris arundinacea, Scheuchzeria palustris, Scirpus spp., Trientalis europaex var. arctica, etc. In the early summer when the silky cotton-grass displays its beauty, blue Irises (I. lavigata and $I$. setosa) take their part in adorning the swamp. Pretty orchids such as Arethusa japonica and Pogonia japonica, the blue Gentiana Thunbergii, the tall Viola Langsdorffi, and the white Spiraa betulifolia, present a delightful sight. Tall Umbelliferæ such as Angelica and Hevacleum, which remind us of the scenery of the arctic vegetation, line the margin of the swampy places in the summer, but in the autumn these are replaced by the huge Senecio palmatus with yellow flowers, and the deep blue Gentiana jesoana is fully open.

In the ponds and lalses one often sees Hippuris vulgaris, Polygonum amphibium, Potanogeton natans, P. perfoliatus, with which Fontinalis, Lemna trisulca and Utricularia minor are occasionally associated.

In the deciduous woods, on hillsides, and even on the fairly high mountains, Sasa paniculata, S. kurilensis and S. nipponica are very abundant. These bamboos have comparatively thin culms and broad leaves, and form very dense thickets, under which various shade-loving plants find protection.

The characteristic forest trees are the deciduous oalks $(Q$. dentata, $Q$. glandulifera, and $Q$. grosseserrata), birches $(B$. alba, $B$. Ermani, B. Maximowieziana), cherries ( $P$. Maximorviezii, and $P$. serrulata), elm ( $U$. japonicus), hornbeam ( $C$. cordata), maples ( $A$. japonicum, $A$. Mayri, and $A$. pictum), poplars ( $P$. suctveoleus and $P$. tremula), and Cercidiphyllum japonicum. The last-named is a very peculiar tree, the sole representative of the family Cercidiphyllacer. Its general appearance closely resembles that of Ginkgo, so that it has often been mistaken for the latter by casual travellers. ${ }^{1}$ Various

2 cf. Hemsley, Ind. Fl. Sin. ii, p. 547; also Ann. Bot., xiv, p. 119. 
kinds of Salix are very often found in more or less damp places. Conifers are not rare, but comparatively few species are present, e.g., Abies Mariesii, A. sachalinensis, Funiperns chinensis var. procumbens, Larix dahurica, L. kurilensis, Picea ajenensis, P. Glehni, and Taxus cuspidata. Pines are rare except in cultivation. The only wild species is $P$. pumila which is usually three or four feet, occasionally five to seven feet in height, and generally grows on mountain summits. Thujopsis dolaborala, one of the finest Conifers, grows to a great size in the southernmost part of this region.

Even in Saghalien and the Kuriles we often meet with several woody climbers, such as Actinidia arguta, A. Kolomiktı, Celastrus articulatus, Hydrangea scandens, Rhus Toxicodendron var. radicans, Vitis Thunbergii, etc., which grow in tropical luxuriance. Not only here, but also in other parts of Japan, we frequently find many woody climbers. Sargent attributed this fact to the abundant undergrowth of bamboos, which cuts off most of the light, and makes the plants climb up the trunks of other trees.

On the high peaks which are not much more than 7,000 feet in altitude, we find many interesting arctic plants such as Bryanthus and Phyllodoce generally growing on exposed rocks.

The vegetative period of this region is very short. Still, as soon as the spring arrives, everything is quite ready for rapid growth, and before September comes with the keen autumn wind, seeds are set and dispersed.

2. Middle Region. This region is very extensive and mountainous, so that the vegetation is not uniform.

The coasts are beautifully lined with graceful pine trees. Pinus Thunbergii, which is well adapted to sandy sterile localities, is the species most often found on the sea shore. The following plants are some of the representatives of the sand-dune plants:-Amodenia

- peploides var. oblongifolia, Arabis japonica, A. perfoliata, Artemisia Fukudo, Arundo donax, Bahmeria biloba, B. holosericea, Calystegia Soldanella, Carex macrocephala, C. Pierotii, C. pumila, Cinidium japonicum, Crepis lanceolatu, Crinum asiaticum var. declinatum, Corydalis platycarpa, Dianthus japonicus, Fimbristylis spathacea, F. velutina, Ischamum anthephoroides, I. Sieboldii, Lactuca repens, Lathy'rus maritimus, Linaria japonica, Lubinia lubinioides, Phellopterus littoralis, Rhaphiolepis japonica, Samolus floribunda, Sedum oryzifolium, Statice japonica, Vitex trifoliata var. orata, Wedelicu procumbens. Rocky cliffs are infrequent, nor do they present a gay 
appearance as they do in the Northern Region. The species growing in this sort of locality are comparatively few, such as Chrysanthemum Decaisneanum, C. marginatum, Cotyledon spp. Sedum spp., Polystichum falcatum, and so forth.

The forest trees of this region are of great variety. Evergreen trees occur largely and broad-leaved species are especially numerous. In the spring trees and shrubs with conspicuous flowers such as different kinds of Azalea, Prunus and Pyrus decorate the woods on every hand, and in the autumn the foliage of various deciduous trees displays gorgeous hues. More species of Pinus appear in this region, and Cryptomeria, one of the most beautiful trees in Japan, flourishes here. The tall bamboos, mostly belonging to the exotic genus Phyllostachys add a special feature to the vegetation. They are almost exclusively under cultivation, and form dense groves. The largest of them $(P$. edulis) exceeds 30 feet in height, the base of the culm measuring as much as 10 inches in diameter.

The uncultivated fields, which are called "hara" in general, are usually covered with a dense growth of Miscanthus and other grasses, amongst which grow small shrubs and thousands of herbaceous plants, including the fine Lilium auratum, that prefer dry sunny situations.

This middle region contains the huge mountain ranges with perpetual snow lying in the gulleys, of which I have already spoken. The flora of these mountains generally presents zones of different vegetation, as we ascend from below to the summit.

Taking Mount Fuji, which is the highest volcano in Japan, and is moreover the world-famous "peerless mountain ", as a type, we shall find the mountain-flora of a temperate country. This peak stands practically on a plain, and if one likes, one can start climbing from the very seashore. Supposing we take a village at the southern base of the mountain as a starting point, then we shall ascend, first of all, a long gentle slope. This is composed of lava and cinders, and is almost useless for cultivation. Various sorts of grasses, $R u b i$, wild roses, and bracken cover this wide area, and small shrubs and trees grow in scattered spots. In the summer thousands of herbaceous plants with yellow, pink, blue, white or purple flowers convert the wilderness into a splendid flower garden, where one often comes across many a gorgeous butterfly. Small patches of alluvial soil deposited by the action of water are seen here and there. In such places many interesting trees such as Abies 
firma, Acer spp., Castanea sativa, Cephalotaxus, Cinnamomum Camphora, C. pedunculatum, Cryptomeria japonica, Diospyros Kaki, Eurya japonica, Larix leptolepis, Listea aciculata, L. glauca, Pasania cuspidata and Quercus spp. are to be found, partly wild and partly planted.

At the 3,000 feet level the basal zone which we have just passed, begins to show a transition to the tree zone. The tree zone may be divided into the deciduous tree belt and the conifer belt, the former taking the lower part and the latter occupying the upper portion. The broad-leaved trees growing here include the following:-Acer, Alnus, Betula, Carpinus, Cercidiphyllum, Cornus, Corylus, Euptelea, Euonymus, Hydrangea, Quercus, Stephanandra, Viburnnm. Very many shade loving plants form the undergrowth. In the conifer belt, Abies firma appears first, and this is followed by Larix, Picea, Tsuga, and other species of Abies. Mosses and liverworts form a thick cushion on rocks and trunks, and with these occur a number of interesting ferns and orchids.

When we reach the 6,000 feet level, the gradient becomes much steeper, and trees are less abundant. The mountain ash, Rhododendron, Alnus spp., stunted birches, shrubby Spiraa, dwarf willows and various ericaceous shrubs remind us that we are reaching the shrub zone. The flowers we meet with here are mostly of alpine character. Species of such genera as Adenophora, Arabis, Artemisia, Astragalus, Clematis, Geranium, Patrinia, Polygonum, Stellaria, and Thalictrum are quite different from their congeners growing down below.

The zone between 7,500 feet to 10,000 feet from sea-level belongs to the Alpine region. Plants growing in this zone are typically alpine and arctic. Arabis serrata, Artemisia pedunculosa, Astragalus membranaceus, Clematis alpina, Hedysarum esculentum, Polygonum cuspidatum forma colorans, Stellaria florida var. angustifolia, Vaccinium Vitis-Idcea are the plants which commonly occur here.

Above this up to the summit, which is about 12,450 feet above sea-level, is the Lichen zone, where one comes across various lichens such as Cetraria islandica forma angustifolia, Cladonia rangiferina, Rhizocarpon geographicum and Stereocaulon octomerum. Here and there those plants which we have seen in the Alpine zone grow in crevices of the lava, but they do not thrive as they do some way further down. 
Practically the whole area of the summit is occupied by a large crater not far short of 2,000 feet in diameter, which is surrounded by a series of small rugged peaks. Two springs of very pure cold water supply the demands of crowds of mountaineers.

The Alpine zone of Mount Fuji does not contain many plants, though there are a few things only known from this mountain. On the other mountains of Central Japan, which form the back-bone of the main island, and are often called the Japanese Alps, the Alpine vegetation is very well developed. On these mountains a creeping pine, Pinus pumila which also occurs in Siberia, appears in the shrub zone, and extends to the Alpine zone. The thickets of this pine are very troublesome to cross, but under their shade various interesting plants are found, e.g., Coptis trifolia, Fritillaria camtschatcensis, Linncea borealis, Lycopodinn alpinum, L. Selago var. appressum, Listera cordata and other orchids, Rubus pedatus, Viola biflora, V. crassa, and so forth. Many arctic plants which occur on the rocky cliffs of the Kuriles can also be found in the Alpine zone of these mountains. One of the most attractive things is Dicentra pusilla. This plant is about a span high, with much dissected, intensely glaucous leaves, and a terminal raceme bearing some half-a-dozen large pink flowers. A beautiful sight is a carpet made up of the crimson flowers of Primula cuneifolia with white patches of Anemone narcissiflora Mosaics of the crimson Geraninm yezoense var. nipponicum, the golden-yellow Rannnculus acris var. Steveni and Trollins patilus, and the blue Aquilegia siberica var. flabellata are another sight of the Alpine zone. On the rocks we occasionally find Campanula lasiocarpa, C. pilosa var. dasyantha, Diapenisia lapponica var. obovata, Empetrum nigrum, Eritrichinm nipponicum, Geum calthaefolium var dilatatum, Hypericum camtschaticum, Lloydia alpina, Saxifraga bronchialis var. cherlerioides, Sedum Rhodiola var. Tachircei, and so on. In the crevices of the rocks the very peculiar looking Cassiope lycopodioides grows, while its congener $C$. Stellariana prefers a moist place. Dryas is very rare, and is known only from four or five localities, but it is replaced by a member of the same family, namely Geum dryadoides which has white flowers and bearded achenes. The species of Ranunculus with white flowers are totally unknown from the Japanese Alps, while Soldanella is replaced by a member of the Diapensiacer called Shortia soldanelloides. Neither Cyclamen nor Sempervivum grow in any part of Japan. One of the rare and interesting plants is Anemone Taraoi, ${ }^{1}$ with a pale

1 For a description, see Journ. Bot., 1910, p. 266. 
yellow flower, which though it has a similar appearance to $A$. sulphurea, belongs to a different subgenus. This plant is endemic to Japan and occurs only on the summits of a few high mountains and in the Kurile Islands. When, in the late summer or early autumn, the frost has made the leaves of Arctous alpina bright red, a mountaineer will enjoy ripe fruits of various species of Vaccinium, Prunus, Lonicera, and Empetrum. In rather dry sandy places one often finds species of Adenothora, Arnica, Draba, Euphrasia, Gentiana Loiseleuria, Oxytropis, Potentilla, and some grasses such as Deschampsia and Festuca, while in humid localities Alchemilla, Fauria, Pedicularis, Phyllodoce, Sibbaldia, Swertia, Tofieldia, and Veratrum are to be found. The ferns growing on the rocks are few, but elegant, and include Asplenium viride, Cryptogramme crispa, Polystichum Lachenense and Woodsia ilvensis. While most of these ferns occur in Europe, the Polystichum is only known from the Himalayas. Botrychium Lunaria, not at all uncommon in Europe, is comparatively rare in Japan, and $B$. lanceolatum is perhaps the rarest. A good many new species of plants have been discovered and described from the Japanese Alps, while many known species have been found and added to the flora. On the whole the Alpine flora of Japan is mostly composed of arctic plants, some of which are not seen on the European Alps.

Finally the aquatic vegetation of the middle region may be mentioned. There is a great diversity in the representatives of aquatic plants. The commonest genera which we find in nearly every pond, ditch, or lake are perhaps as follows:-Alisma, Ceratophyllum, Hydrilla, Hydrocharis, Lemna, Monocharia, Myrio. phyllum, Nuphar, Nymphaea, Ottelia, Phragmitis, Potamogeton, Rotala, Sagittaria, Scirpus, Trapa, Typha, Utricularia, Vallisneria and Zizania. Besides these flowering plants, water ferns such as Azolla, Marsilia, and Salvinia occur in the stagnant water. Isoetes japonica, which is one of the largest species of this genus, is to be met with in running water in certain places,

3. Southern Region. We will now pass to the Southern Region, where, even at its northern limit, Kyûshû, the vegetation is quite sub-tropical. Particularly on the sea-coasts, which are washed by the warm current, various Indo-Malayan strand plants are to be met with. In the Loochoos, Bruguiera gymnorhiza forms the mangrove-forest in the tidal estuaries. Well-developed mangrove-forests are to be seen in Formosa, which are composed of 
Avicennia officinalis, Kandelia Rheedii, and Rhizophora mucronata. In such marshy places one finds such plants as Halophylla, Scavola, and Suceda australis. On the sandy beach we often get Barringtonia spp., Cassytha filiformis, Ipomaca biloba, Pandanus spp., Peperomia portulacoides, Vigna lutea and so forth. Various palms belonging to such genera as Arenga, Livingstonia, Trachycarpus, and so on, flourish in the Region.

This is really a region of Ficus, with which broad-leaved evergreen trees and shrubs such as various Lauraceæ, Quercus, Hibiscus, Myrica rubra, etc. are found. On their branches a great many epiphytic orchids, lycopods and ferns, and sometimes parasites such às Loranthus spp. and Viscum japonicum are found. In the dense moist forests many tropical ferns such as Allantodia javanica, Also. phila, spp., Angiopteris evecta, Cyathea, Dicksonia, Gleichenia spp., Osmunda javanica, Pteris quadriaurita, $P$. wallichiana flourish. Amongst other woody climbers I may mention the occurence of Bauhinia japonica in Kyûshû. In the Loochoos we get more tropical plants such as Garcinia, Pinus luchuensis, Terminalis Katappa and others. The famous Cycas revoluta thrives very well in these islands, and from its pith a sago is prepared. Various interesting orchids and ferns including Helminthostachys zeylanica are also to be met with.

If we pass over the Loochoos and come to Formosa, the vegetation is typically tropical. Although the climate is not uniform throughout the island, huge trees, thick bushes, dense forests with a great number of woody climbers can be found everywhere. In the mountain valleys we frequently come across Cinnamonum camphora, from which the camphor of commerce is obtained, reaching huge dimensions. Macuna gigantea and Pusatha scandens, both famous for their tremendous legumes, other climbers such as the Lotung, and gigantic bamboos, tall tree ferns, palms, and the wild Musa grow in the forests and on mountainslopes. If we go higher up on the mountains which occupy the greater part of the island, we shall see conifers at an elevation of about 6,000 feet above sea-level. Chamacyparis formosensis, Cunninghamia Konishii, Picea morrisonicola, and Pinus formosana are some of the interesting species, and are only known from this island. A few years ago a new genus of conifer was discovered amongst the mountains, about $6-8,000$ feet above the sea. The external appearance of this tree is somewhat similar to that of Cryptomeria, so that people thought at first that they had found a 
wild Cryptomeria, until the cone was obtained and closely examined. Then the plant proved to be a new genus and was accordingly named Taiwania cryptomerioides in honour of this beautiful island. The systematic position of this genus was suggested to be between Athrotaxi and Cunninghamia; further investigations, both anatomical and cytological, are much to be desired.

Higher up on the mountains we first get the shrub-zone and then at an elevation of 12,000 feet and upwards various plants of alpine and arctic character, such as Arabis, Artemisia, Cerastium, Deschampsia, Festuca, Fragaria, Gentiana, Gnaphalium, Leontopodium, Luzula, Potentilla, Shortia, Sibbaldia, Trisetum sub. spicatum, and so forth.

If we go down to the southernmost part of the island, we shall everywhere meet with nothing but real tropical plants, and the vegetation shows a close relationship to that of the Philippines, India, and Java. Certain elements belonging to Cochin-China and of southern China will also be detected.

Roughly speaking, there are some 2,500 species (belonging to some 770 genera) of higher plants known, $17 \%$ of which are endemic ; and many more will be discovered in the future in this island which promises so much to the enthusiastic botanist.

\section{Vi.-Cultivated Crops.}

A few words may perhaps be added on this subject. The most important plant is undoubtedly the rice-plant, Oryza sativa, with a great many cultivated varieties and races. The plant is grown throughout the country with the exception of Saghalien and the Kuriles. Particularly in Central and S.W. Japan, every possible piece of land is converted into rice-fields, which present a very striking feature to the eye familiar only with European scenery. A rice-field is, in a word, a muddy swamp divided up by low narrow banks into more or less square areas. The plant is raised in the nursery and seedlings of about a span high are transplanted from this into the rice-field proper. In the summer the rice-field is of a delightful green colour; in the autumn it turns somewhat golden, as the grain ripens and the plant withers. In the winter, after the harvest, the rice-field looks quite desolate, but often furnishes the best shooting-ground for snipe and other game-birds. Sometimes the rice-plant is also grown in dry fields where water is not available.

In Saghalien and the Kuriles, the temperature is very low during more than half the year, so that cultivation is hardly to be 
hoped for. The vegetation of these districts is little touched by human hands, so that the original features are exceedingly well seen.

In Yezo, except perhaps its eastern parts, the temperature rises considerably in the summer, so that various sorts of grain and vegetables are produced, and especially excellent varieties of apple. The cultivation of the hop and flax, which meets with considerable success, may also be mentioned.

In the Middle Region, plains and small hills are cultivated with rice, other grains, beans, peas, cucumber, egg-plant, radishes, turnips, mustard, Lagenaria, Colocasia antiquorum, potatoes, sweet potatoes, and so forth. Besides these vegetables one often comes across the cotton-plant, hemp, tobacco-plant, and mulberry, the last of which is utilized for sericulture. Various fruit-trees such as apricot, fig-tree, peach, pear, persimmon, orange, vine, and Eriobotrya are also grown. Nor must I omit to mention the tea-plant, and paper mulberry and Edgeworthia for paper manufacture. Various species of the bamboo, Phyllostachys, which, as already said, form a peculiar feature in the warmer parts of Japan and were probably introduced from China at an early period, yield valuable material for various purposes. Fences, pegs, baskets, arrows, trellis-work, hoops for barrels, shafts of umbrellas, cages, and fishing rods can be made out of the culm, while the sheath of the young shoot is useful for wrapping or for making hats or sandals. There are a good many species of bamboo, belonging to Arundinaria, Bambusa, and Sasa, used for similar purposes, or much valued as ornamental plants. A species of Dendrocalamus, from which a kind of paper can be manufactured, grows in Formosa.

As a matter of course sub-tropical and tropical crops are grown in the Southern Region. In addition to those mentioned above in the Middle Region, there are such plants as bananas, coco-nut, pineapple, and sugar-cane. Musa luchuensis yields a fibre of good quality, while an excellent kind of hat can be made out of the leaves of a screwpine. Tetrapanax papyrifera, from the pith of which the so-called rice-paper is prepared, grows in Formosa.

\section{VII.-Introduced and Garden Plants.}

In this last chapter I may perhaps deal briefly with gardening and garden plants.

Gardening must have been introduced from China together with other arts and especially with Buddhism. Buddhist priests may have been the first to construct gardens after the Chinese patterns, 
which was greatly modified in later years. So far as I know, one of the famous gardens, designed some 500 years ago, still exists.

Generally speaking, the gardens are very different from European ones. Geometrical carpet bedding and lawns are quite unknown, and beds are used only in the nursery. Rather different from the original Chinese gardens, which are more artificial and Gothic, the Japanese gardens are miniatures of natural landscape. Generally, there is a small hill or two, a pond, a bridge, and a few stone lanterns. This is copied (very badly) on a small scale and exhibited at the Temple show every year. Trees and shrubs are mostly used, and comparatively few herbaceous plants are grown. Pines and Chamacyparis are indispensable. Except Abies firma, which is hardy in the lowlands, other species of this genus and Picea are hardly ever seen, while a dwarf variety of Taxus cuspidata and Funiperus chinensis are sometimes used. Broad-leaved evergreen trees and shrubs are mixed with deciduous plants. Half-a-dozen species of Prumus are planted for the sake of their flowers, while a great many varieties of Acer palmatum and other species of maple are grown for their foliage. Ferns are usually neglected except for a few hardy species. Amongst shrubs many linds of Azalea, with Cydonia, Nandina, and Pynus floribunda are favourites, while Wistaria is often planted over a pond. Stones and rocks of different colour and shape are always placed in certain definite positions, and sometimes even a small cascade is reproduced falling over a rock. There are several types of gardening, the principles of which are not very easily understood; some trees, shrubs, and stones should occupy a certain position, trees should have certain ramifications, and certain shrubs should be trimmed in definite ways.

In some cases, a landscape garden is skilfully reproduced in a box or in a pot. One of the best examples which was transferred from the Japan-British Exhibition can be seen in Battersea Park, London. For this purpose the plants used must necessarily be small, but perfect in style and shape.

The dwarf pot trees, which appear somewhat mysterious, even to a scientific eye, may also have been introduced from China. The art has been improved with great skill. Not only arboreal plants but also various other evergreen plants such as Acorus gramineus, Rhodea japonica, and even Psilotum triquetrum became material for pot cultivation. Some are grown for their flowers, others for fruit, or foliage. In some years variegated leaves of any plant are much valued, in other years Chamceyparis is in fashion, and so forth. 
Curiosity drove people into little explored parts of the country to discover curious or unusual plants for this purpose. Also, very many plants were imported from China and Corea or even from the tropics. The introduction of foreign plants took place not only in recent years, but in ancient times for economic, pharmaceutical, and other purposes. Cryptomeria japonica, for instance, which is so widely cultivated all over the country, is said to have been imported from Corea in prehistoric times. Rice and various other grains must have been brought by our ancestors from somewhere abroad History tells us that the orange, or at any rate a kind of orange was imported for the first time in the year 70 A.D. The Corean medical art was introduced into Japan in 510 , and with this came also pharmaceutical botany. In 701 a physic garden was established, and medical botany was taught there. Afterwards very many plants possessing medical value were introduced from China and Corea, and in later years many economic and garden plants also. Sometimes the introduction was made quite by chance, e.g., in 799 a foreigner is said to have arrived in Central Japan, having drifted ashore on the waves, and he brought with him some seeds of the cotton-plant.

These introduced plants were not always indigenous to China or Corea. The Chinese imported various plants into their own country from their southern and western neighbours; e.g., according to the history of the Han, the Chinese General Chang K'ieng who was despatched about 139 B.C. by the Emperor Wu on a diplomatic mission to a neighbour living to the north-west of China, brought back the vine from western Asia about 120 B.C. After the discovery of America, very many American plants were introduced by the Spaniards and Portuguese into the Philippines and the East Indian Archipelago. Their cultivation spread rapidly over the neighbouring parts of the Old World, ar i they found their way also into China. These plants may possibly have been imported into Japan directly or through China, and throve there equally well with the indigenous forms.

The first European who came over to Japan and made a botanical collection was Andreas Cleyer. He came with a Dutch Ambassador about 1675, and stayed in Western Japan four years. Afterwards he published a book containing illustrations of 1,360 species of plants. Then George Meister who lnnew Cleyer arrived in Japan in a similar manner, and published in 1692 an account of his journeys and observations. Just after him, in 1690, Engelbert 
Kaempfer reached Japan and stayed three years. He was the first to illustrate Ginkgo in his book published in 1712. After some ninety years, Thunberg who was a pupil of Linnaeus came over to Japan, studied the plants and published his Flora Faponica in 1784. He also published an account of his journeys and illustrations of some Japanese plants. I am not quite certain if these people brought back seeds or plants from Japan, but there is no doubt about Von Siebold who came over some forty years later, and took a few living animals and plants away with him.

Robert Fortune, who paid repeated visits to China during eighteen years from 1843, sailed to Japan in 1860 and again in 1861. He saw a number of interesting plants there and introduced several garden plants. About the same time John Gould Veitch went over to Japan for the purpose of obtaining garden plants, and introduced a great many plants into English gardens in 1861 . Amongst others the following few are perhaps worthy of note:Adiantum Veitchii (=A. monochlamys.), Ampelopsis Veitchii (=Parthenocissus tricuspidata), Abies Veitchii, A. Alcockiana, Cryptomeria jafonica var. elegans, Lilium auratum, Picea ajanensis var. microcarpa, Polypodium Veitchii, Primula cortusoides var. elegans (=P. Sieboldii), Selaginella involvens var. Veitchii.

Messrs. Standish and Noble of Bagshot Nursery were the first to cultivate the new Chinese plants discovered by Fortune. They also received the following Japanese plants obtained by that distinguished collector:-Aucuba japonica, Deutzia crenata, Tricyrtis hirta, etc.

J. G. Veitch was followed by Maries who also collected many dried specimens which are now preserved at Kew, and I have had an opportunity of examining and naming some of them.

These people saw in Japan very many interesting and curious plants and certainly thought all of them were indigenous to Japan, and a number of the new species were named "japonica." In fact some of these are not true natives of Japan, but are merely cultivated in the gardens. For instance, Cydonia japonica, generally known under the name of "japonica" in this country, is of Chinese origin. Eriobotrya japonica which is so much grown on the northern coasts of the Mediterraneans, is probably not a native of Japan. Mahonia japonica is another plant, which was described from a specimen grown in a Japanese garden, was introduced into

I The narratives of his journey were published under the title of "Notes on the Botany of Japan" in Gard. Chron., 1861, pp. 145, 312, 385, 456, 576, 737. 
Japan in 1684 probably from China, where until to-day no true $M$. japonica has been collected, but an allied plant occurs, M. Bealei, which has been taken for the other one in this country. The beautiful garden Chrysanthemum, which is the national flower of Japan, was certainly introduced from China, yet the wild form, the original of the garden variety, grows in the south-western parts of Japan. Nowadays a great number of European and American plants are introduced into Japanese gardens, while quantities of Japanese plants are exported to foreign countries and especially to England, where it always gives me the intensest joy to see the plants of my native land. 


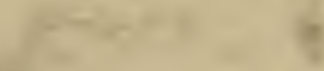

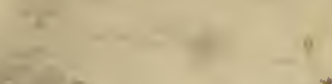

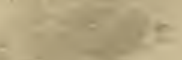

7

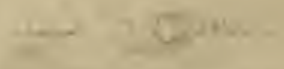

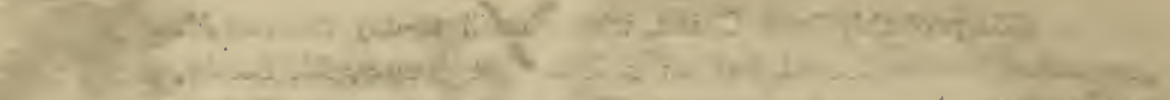

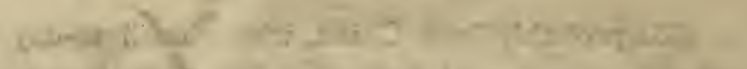

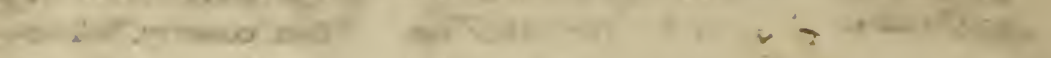
$-17 \leqslant-17$ $+1$ . 3.

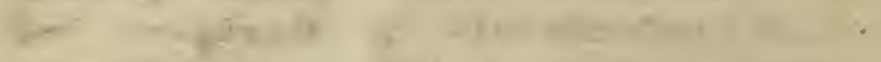
$+2 x+7<-7+2$ + $+1+2,+4$

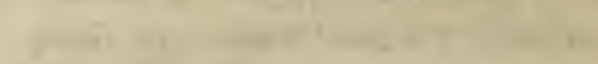
i 9 r

r $20-4$

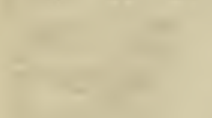

4

"

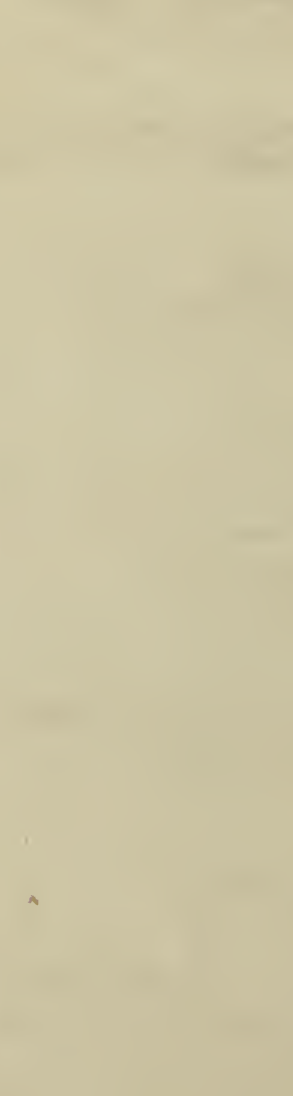


, 
UNIVERSITY OF ILLINOIS-URBANA

581.952T13V

THE VEGETATION OF JAPANSCAM

COO1
ANSCAMB

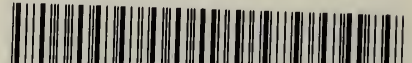 |||||||||||||||||||||||||||||||||||||||||||||||||||||||||||||| 30112009947265}

